\title{
Dried beet pulp, pressed beet pulp and maize silage as substitutes for concentrates in dairy cow rations. 2. Feed intake, fermentation pattern and ruminal degradation characteristics
}

\author{
H. DE VISSER, H. HUISERT \& R. S. KETELAAR \\ Research Institute for Livestock Feeding and Nutrition, P.O. Box 160, NL 8200 AD \\ Lelystad, Netherlands
}

Received 7 June 1990; accepted 14 November 1990

\begin{abstract}
Four rumen-cannulated dairy cows were fed twice daily with a totally mixed ration (TMR), in which the basal diet consisted of artificially dried grass, maize silage and concentrates. In addition, $25 \%$ of total dry matter intake was dried beet pulp (BP), ensiled pressed beet pulp (PP) or extra maize silage (M). The measurements were performed at approximately 15 (LLI) and $25 \mathrm{~kg}$ (HLI) dry matter feed intake respectively in a $2 \times 3 \times 4$ latin square design. Measurements were made of organic matter degradation (nylon bag) of diet ingredients, while during 48 hour periods the pattern of intake, $\mathrm{pH}$ and osmolality, as well as the concentration of volatile fatty acids (VFA), lactic acid (HL) and ammonia $\left(\mathrm{NH}_{3}\right)$ were determined. The $\mathrm{pH}$ and concentration of the major VFA's did not differ significantly between treatments. The concentration of the branched chain fatty acids (BCFA), valerate and ammonia were significantly higher for diet $\mathrm{M}$. The level of intake significantly influenced the $\mathrm{pH}$, concentration of the major VFA's, 2-methyl-butyrate and valerate. The feed intake pattern differed between intake levels, but were similar for the three diets. The results of the degradability of treatments were calculated from individual degradability measurements of diet ingredients. The undegradable fraction $(U)$ was highest for diet $\mathrm{M}$. The water-soluble fraction $(S)$ was lowest for treatment DP, and the rate of degradation $\left(k_{\mathrm{d}}\right)$ was lowest for treatment M.
\end{abstract}

Keywords: cow, rumen, degradability, vfa, lactic acid, ammonia, beet pulp, maize silage

\section{Introduction}

Beet pulp is a by-product from the sugar beet industry, which is available to farmers either moist or as a dehydrated product. The moist product involves lower production costs (no drying costs), but is bulky (transport) and must be ensiled. There is a shift in utilization of beet pulp in Dutch dairy feeding from dried beet pulp to pressed ensiled beet pulp. Recently reported information suggests, that the energy values of both beet pulps are high and do not differ significantly from each other (Hemingway et al., 1986; de Visser \& Tamminga, 1987; de Visser \& Hindle, 1990).

Dutch dairy cow rations usually contain large quantities of partly fermented 
roughage(s), grass silage and/or maize silage. In early lactation, large amounts of compound feeds are fed as supplement to the roughage-based diets of high-yielding dairy cows in order to meet requirements. These concentrates can be partially replaced by moist-ensiled by-products, such as pressed ensiled beet pulp, ensiled maize gluten feed or moist ensiled brewers' grains. Dried beet pulp on the other hand is used by the compound feed industry as an important energy rich ingredient in concentrate mixtures. An alternative for dairy farmers may be the use of an energy-rich roughage, such as maize silage.

Replacing concentrates with pressed ensiled beet pulp or maize silage (both partly fermented by micro-organisms in the silo) may have a negative influence on rumen fermentation. During the ensiling process part of the energy in the feed (carbohydrates) is converted into the end-products of fermentation such as volatile fatty acids and lactic acid. These fermentation products cannot be used as efficiently as the original carbohydrates by the micro-organisms in the rumen (van Soest, 1982; Robinson et al., 1987).

Therefore a comparative study was performed, in which pressed ensiled beet pulp was compared to dried beet pulp and maize silage. The objectives were:

1. To measure the influence of pressed ensiled beet pulp, dried beet pulp or maize silage on rumen fermentation patterns.

2. To measure the influence of two feeding levels ( 15 and $25 \mathrm{~kg}$ DM per animal per day) on these patterns.

3. To measure the degradation characteristics of the organic matter of pressed ensiled beet pulp, dried beet pulp and maize silage using nylon bag incubations.

4. To explain the results of a feeding trial, in which the same dietary ingredients were applied (de Visser \& Hindle, 1990).

\section{Materials and methods}

\section{Rumen fermentation}

The 4 animals used in this experiment were of the Dutch Friesian and Dutch Friesian $\times$ Holstein breed and were each equipped with a rumen cannula. One cow was fitted with a PVC cannula of $5 \mathrm{~cm}$ i.d. (Eriks, Alkmaar, the Netherlands). The other three animals were equipped with a large rumen cannula of $10 \mathrm{~cm}$ i.d. (BarDiamond Inc., Parma, ID, USA). The animals were housed in a tie stall and in order to avoid selection they were offered a totally mixed ration (TMR), using a mixer-forage wagon.

The diets corresponded to those of the accompanying feeding trial (de Visser \& Hindle, 1990) and are shown in Table 1. The treatments were dried beet pulp (DP), pressed ensiled beet pulp (PP) and extra maize silage (M). The animals were fed individually twice daily; at 5:00 h ( $40 \%$ of the diet) and at $14: 00 \mathrm{~h}(60 \%$ of the diet). The composition of the concentrate mixture was as described by de Visser \& Hindle (1990) and consisted of coconut expeller (5\%), maize gluten feed $(38.5 \%)$, palm kernel expeller $(8.3 \%)$, soya bean meal solv. extracted $(24.3 \%)$, soya bean hulls $(15 \%)$, cane molasses $(5 \%)$, minerals and vitamins (3.9\%). Rumen fermentation 
Table 1. Diet ingredients and chemical composition, after correction for volatiles $\left(\mathrm{g} \mathrm{kg}^{-1} \mathrm{DM}\right)$.

\begin{tabular}{|c|c|c|c|}
\hline & $\begin{array}{l}\text { Dried beet pulp } \\
\text { (DP) }\end{array}$ & $\begin{array}{l}\text { Pressed beet pulp } \\
\text { (PP) }\end{array}$ & $\begin{array}{l}\text { Maize silage } \\
\text { (M) }\end{array}$ \\
\hline \multicolumn{4}{|l|}{ Diet ingredient } \\
\hline $\begin{array}{l}\text { Artificially dried grass } \\
\text { Maize silage } \\
\text { Dried beet pulp } \\
\text { Pressed beet pulp } \\
\text { Concentrate mixture }\end{array}$ & $\begin{array}{l}200 \\
200 \\
250 \\
- \\
350\end{array}$ & $\begin{array}{l}200 \\
200 \\
- \\
250 \\
350\end{array}$ & $\begin{array}{l}200 \\
430 \\
- \\
- \\
370\end{array}$ \\
\hline \multicolumn{4}{|l|}{ Chemical composition } \\
\hline $\begin{array}{l}\text { Dry matter } \\
\text { Ash } \\
\text { N-Dumas } \\
\text { Crude fat } \\
\text { Crude fibre } \\
\text { Neutral detergent fibre } \\
\text { Starch } \\
\text { Sugar }\end{array}$ & $\begin{array}{r}746 \\
94 \\
27 \\
25 \\
198 \\
455 \\
76 \\
64\end{array}$ & $\begin{array}{r}568 \\
94 \\
28 \\
25 \\
198 \\
475 \\
76 \\
45\end{array}$ & $\begin{array}{r}599 \\
88 \\
28 \\
31 \\
202 \\
459 \\
132 \\
38\end{array}$ \\
\hline
\end{tabular}

1 De Visser \& Hindle, 1990.

Table 2. Experimental design.

\begin{tabular}{lllll}
\hline Period & \multicolumn{2}{l}{ Cow No } & & \\
\cline { 2 - 4 } & 744 & 773 & 829 & 1338 \\
& & & & \\
1 & $\mathrm{H}^{1}$ PP $^{2}$ & L DP & H DP & L M \\
2 & H M & L PP & H PP & L DP \\
3 & H DP & L M & H M & LPP \\
4 & L DP & H DP & L PP & H M \\
5 & L PP & H PP & L M & H DP \\
6 & L M & H M & L DP & H PP \\
\hline
\end{tabular}

${ }^{1}$ Feeding levels: $\mathrm{H}=$ HLI (high level), $\mathrm{L}=$ LLI (low level).

2 Diets: $\mathrm{DP}=$ dried beet pulp, $\mathrm{PP}=$ pressed ensiled beet pulp, $\mathrm{M}=$ maize silage.

pattern was investigated at two feeding levels. During the first 5 months after parturition the animals were fed at a high level (approx. $25 \mathrm{~kg} \mathrm{DM}$ ) (HLI), while a low level (approx. $15 \mathrm{~kg} \mathrm{DM}$ ) (LLI) was fed between the 6 and 11th month after parturition.

The experiment was performed as a change over $3 \times 4$ latin square design, which is outlined in Table 2 . It was not possible to perform a complete $6 \times 4$ latin square design, because the animals may have refused the high level of intake during the second part of lactation, or probably had suffered from ketosis when feeding the low level of intake during early lactation. Each period lasted at least 5 weeks. Measurements were made on two consecutive days during the last week of each experimental period. These measurements involved taking 9 samples per day of the ru- 
men fluid at 5:00, 7:00, 10:00, 14:00, 16:00, 19:00, 22:00, 2:00 and 5:00 $\mathrm{h}$ using a plastic tube $60 \mathrm{~cm}$ long with a diameter of $4 \mathrm{~cm}$, which was perforated over the last $40 \mathrm{~cm}$ with holes of $1 \mathrm{~mm}$. A Record syringe was used for the suction of $100 \mathrm{ml} \mathrm{ru}$ men fluid, from the inside of the tube. Samples were directly analysed for $\mathrm{pH}$ and osmolality, using a pH meter (Philips 2000) and an osmometer (Osmomat 300, Gonotec). Subsamples were taken for analysis of volatile fatty acids (VFA), lactic acid (HL) and ammonia $\left(\mathrm{NH}_{3}\right)$. The preservation of these subsamples and the analytical methods used were as described by Robinson et al. (1986).

The results of the individual volatile fatty acids were used to calculate the ratio between the lipogenic and glucogenic volatile fatty acids (NGR) as described by Ørskov (1975). The diets were analysed for dry matter (DM), ash, nitrogen (N), crude fibre, Neutral Detergent Fibre (NDF), sugar and starch as described by de Visser \& Hindle (1990).

During the fermentation study the feed intake pattern of the diets at the two feeding levels was measured by recording the amount of feed consumed between the various rumen sampling times.

All data of the daily rumen samples were used to calculate daily mean values (weighted for time intervals), while the variation during the day was expressed as the standard error of the values measured at the various sampling times during the day. Variance analysis on mean daily values and daily variations in rumen parameters, using the statistical package Genstat (Alvey et al., 1982) were performed using diet and intake levels as independent variables.

\section{Rumen degradation}

Three cows fitted with a large rumen cannula were used. Two of the animals were in early lactation, while the third one was in mid lactation. The animals were fed the intermediate diet ( $1 / 3 \mathrm{DP}+1 / 3 \mathrm{PP}+1 / 3 \mathrm{M})$ from the fermentation study (Table 1 ). The two animals in early lactation were fed 24 and $22 \mathrm{~kg}$ DM per day, respectively, while the third animal was fed $15 \mathrm{~kg}$ DM per day. The animals were housed in the same stall and fed as the animals in the rumen fermentation study.

Rumen incubations were performed for $0,3,6,12,24,48$ and 216 hours to determine the degradation of organic matter (OM). Rumen degradability was measured for all dietary ingredients (Table 1), used in the fermentation study and the feeding experiment of de Visser \& Hindle (1990). The results of the individual feedstuffs were used to calculate the degradability of the three treatment diets (DP, PP, M), using the original data at the various incubation times.

Small samples (approx. $5 \mathrm{~g} \mathrm{DM}$ ) of all ingredients were put into nylon bags measuring $10 \times 19 \mathrm{~cm}$ with a pore size of $41 \mathrm{~nm}$. The dried beet pulp and the compound feed were ground through a $5 \mathrm{~mm}$ sieve. The pressed beet pulp and the maize silage were homogenized with a meat cutter (Duker); the artificially dried grass was chopped into particles of approx. $10 \mathrm{~mm}$ length with a paper guillotine. The procedure for nylon bag incubations and the analytical and mathematical methods employed were as described by van Vuuren et al. (1989).

As a result of these procedures the OM of the feedstuffs was divided into the wa- 
ter-soluble fraction $(S)$, the potentially degradable fraction $(D)$ and the undegradable fraction $(U)$, while the rate of degradation $\left(k_{\mathrm{d}}\right)$ was estimated as the first derivative of the degradation curve. The total potentially fermentable fraction $(F)$, was defined as the sum of $S$ and $D$. Significance tests were performed for differences between feedstuffs and between diets with analysis of variance using the statistical package Genstat (Alvey et al., 1982).

\section{Results}

\section{Rumen fermentation}

The results obtained from the rumen fermentation study are shown in Table 3 . The

Table 3. Rumen $\mathrm{pH}$ and concentrations of volatile fatty acids, lactic acid, ammonia ( $\left.\mathrm{mmol} \mathrm{l}^{-1}\right)$ and osmolality (meq $\mathrm{l}^{-1}$ ), between diets containing dried beet pulp (DP), pressed beet pulp (PP) or extra maize silage (M) and the effects due to level of feed intake (LLI versus HLI).

\begin{tabular}{|c|c|c|c|c|c|c|c|c|}
\hline \multirow[t]{2}{*}{ Component } & & \multicolumn{3}{|l|}{ Rations } & \multirow[t]{2}{*}{$\mathrm{SED}^{1}$} & \multicolumn{2}{|c|}{ Level of intake } & \multirow[t]{2}{*}{ SED } \\
\hline & & $\begin{array}{l}\text { dried } \\
\text { pulp }\end{array}$ & $\begin{array}{l}\text { pressed } \\
\text { pulp }\end{array}$ & $\begin{array}{l}\text { maize } \\
\text { silage }\end{array}$ & & $\begin{array}{l}\text { HLI } \\
\text { high }\end{array}$ & $\begin{array}{l}\text { LLI } \\
\text { low }\end{array}$ & \\
\hline \multirow[t]{2}{*}{$\mathrm{pH}$} & mean & 6.03 & 6.00 & 6.11 & 0.05 & $5.93^{\mathrm{a} 2}$ & $6.19^{\mathrm{b}}$ & 0.04 \\
\hline & range $^{3}$ & 0.38 & 0.38 & 0.32 & 0.03 & $0.32^{\mathrm{a}}$ & $0.41^{\mathrm{b}}$ & 0.02 \\
\hline \multirow[t]{2}{*}{ Osmolality } & mean & 0.304 & 0.311 & 0.310 & 0.01 & 0.313 & 0.303 & 0.01 \\
\hline & range & 0.022 & 0.022 & 0.021 & 0.002 & 0.021 & 0.023 & 0.001 \\
\hline \multirow[t]{2}{*}{ Ammonia } & mean & $7.32^{\mathrm{a}}$ & $6.93^{\mathrm{a}}$ & $9.06^{\mathrm{b}}$ & 0.88 & 7.36 & 8.29 & 0.73 \\
\hline & range & 5.31 & 5.26 & 5.21 & 0.56 & $4.71^{\mathrm{a}}$ & $5.94^{\mathrm{b}}$ & 0.46 \\
\hline \multirow[t]{2}{*}{ Lactate } & mean & 1.46 & 1.75 & 1.38 & 0.24 & $1.26^{\mathrm{a}}$ & $1.87^{\mathrm{b}}$ & 0.19 \\
\hline & range & 2.25 & 2.91 & 2.40 & 0.57 & $1.47^{\mathrm{a}}$ & $3.84^{\mathrm{b}}$ & 0.46 \\
\hline \multirow[t]{2}{*}{ Total VFA } & mean & 118 & 120 & 119 & 4.21 & $126^{\mathrm{a}}$ & $110^{\mathrm{b}}$ & 3.46 \\
\hline & range & 15.7 & 16.4 & 15.4 & 1.43 & $13.7^{\mathrm{a}}$ & $18.7^{\mathrm{b}}$ & 1.17 \\
\hline \multirow[t]{2}{*}{$\mathrm{NGR}^{4}$} & mean & 4.60 & 4.52 & 4.38 & 0.19 & $4.26^{\mathrm{a}}$ & $4.80^{\mathrm{b}}$ & 0.15 \\
\hline & range & 0.50 & 0.41 & 0.47 & 0.07 & $0.33^{\mathrm{a}}$ & $0.62^{\mathrm{b}}$ & 0.06 \\
\hline \multirow[t]{2}{*}{ Acetate } & mean & 74.7 & 76.0 & 73.3 & 2.42 & $78.7^{\mathrm{a}}$ & $69.7^{b}$ & 1.98 \\
\hline & range & 9.45 & 9.80 & 8.77 & 1.19 & $8.1^{\mathrm{a}}$ & $10.8^{\mathrm{b}}$ & 0.98 \\
\hline \multirow[t]{2}{*}{ Propionate } & mean & 22.7 & 23.1 & 23.3 & 1.02 & $25.3^{\mathrm{a}}$ & $19.6^{\mathrm{b}}$ & 0.84 \\
\hline & range & 4.16 & 4.25 & 4.28 & 0.38 & $3.50^{\mathrm{a}}$ & $5.15^{\mathrm{b}}$ & 0.31 \\
\hline \multirow[t]{2}{*}{ Isobutyrate } & mean & $0.71^{\mathrm{a}}$ & $0.71^{\mathrm{a}}$ & $1.00^{\mathrm{b}}$ & 0.11 & 0.84 & 0.77 & 0.09 \\
\hline & range & 0.21 & 0.19 & 0.24 & 0.08 & 0.23 & 0.19 & 0.06 \\
\hline \multirow[t]{2}{*}{ Butyrate } & mean & 16.3 & 15.9 & 16.4 & 0.75 & $17.2^{\mathrm{a}}$ & $14.9^{\mathrm{b}}$ & 0.61 \\
\hline & range & 2.00 & 2.19 & 2.31 & 0.20 & 2.15 & 2.19 & 0.12 \\
\hline \multirow[t]{2}{*}{ 2-Methyl-butyrate } & mean & $0.32^{\mathrm{a}}$ & $0.48^{\mathrm{a}}$ & $1.12^{\mathrm{b}}$ & 0.15 & $0.80^{\mathrm{a}}$ & $0.43^{b}$ & 0.12 \\
\hline & range & $0.17^{\mathrm{a}}$ & $0.22^{\mathrm{a}}$ & $0.61^{\mathrm{b}}$ & 0.16 & 0.42 & 0.24 & 0.14 \\
\hline \multirow[t]{2}{*}{ 3-Methyl-butyrate } & mean & $0.54^{\mathrm{a}}$ & $0.53^{\mathrm{a}}$ & $0.86^{\mathrm{b}}$ & 0.10 & 0.67 & 0.62 & 0.08 \\
\hline & range & 0.20 & 0.22 & 0.27 & 0.06 & 0.23 & 0.24 & 0.05 \\
\hline \multirow{2}{*}{ Valerate } & mean & $1.54^{\mathrm{a}}$ & $1.57^{\mathrm{a}}$ & $1.92^{\mathrm{b}}$ & 0.16 & $1.89^{\mathrm{a}}$ & $1.41^{\mathrm{b}}$ & 0.13 \\
\hline & range & $0.38^{\mathrm{a}}$ & $0.37^{\mathrm{a}}$ & $0.61^{b}$ & 0.09 & 0.45 & 0.46 & 0.08 \\
\hline
\end{tabular}

\footnotetext{
${ }^{1}$ SED $=$ Standard error of difference.

${ }^{2}$ Figures with a different superscript are significantly $(P<0.05)$ different.

${ }^{3}$ Range $=$ calculated as standard error during the day $(\mathrm{SE})$.

${ }^{4}$ NGR $=$ Nonglucogenic Glucogenic Ratio (Ørskov, 1975).
} 

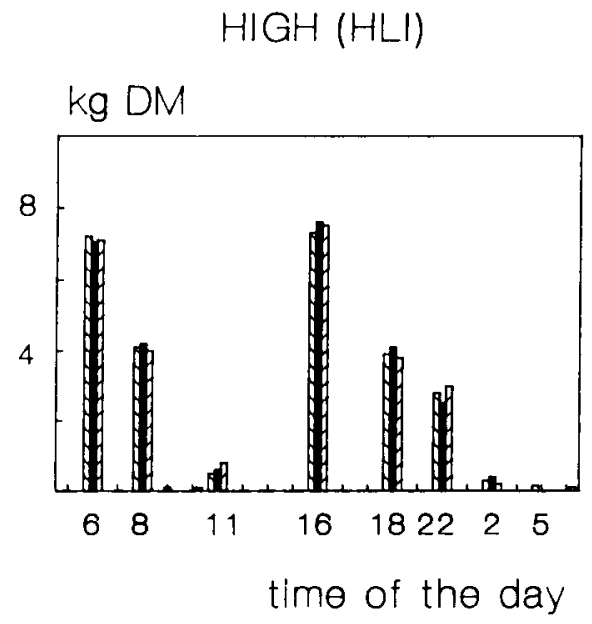

LOW (LLI)

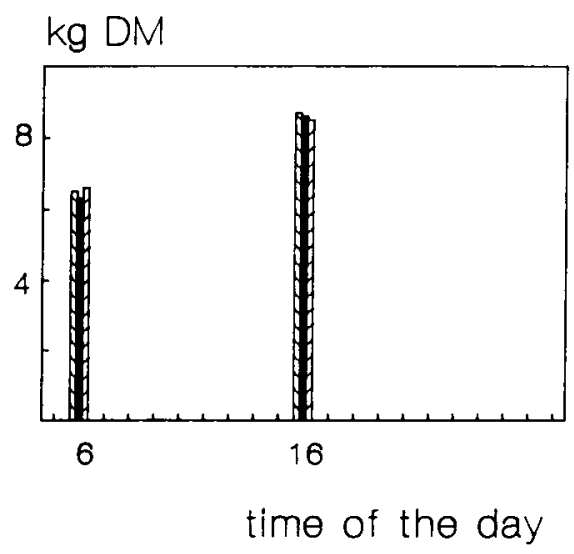

Dried beet pulp (DP)

- Pressed ensiled beet pulp (PP)

ZZ Maize silage (M)

Fig. 1. Feed intake pattern during the day.

mean $\mathrm{pH}$, osmolality, HL, total VFA, NGR, and the major VFA's did not differ significantly between diets. The daily variation in these parameters did not differ significantly either. The concentrations of $\mathrm{NH}_{3}$, the branched-chain fatty acids (BCFA) (iso-butyrate, 2-methyl-butyrate, 3-methyl-butyrate) and valerate were significantly higher for diet M, compared to both beet pulp diets (DP and PP), as was daily variation of 2-methyl-butyrate and valerate.

There was no significant interaction between diet and feeding level. However, feeding level itself significantly influenced most of the rumen parameters. At HLI the concentration of the major VFA's, 2-methyl-butyrate and valerate was significantly higher, while the $\mathrm{pH}$ of the rumen fluid was significantly lower. The daily variation on $\mathrm{LLI}$ was significantly higher for $\mathrm{pH}, \mathrm{NH}_{3}, \mathrm{HL}$, total VFA, NGR, acetate, propionate and butyrate.

Feed intake pattern did not differ between diets, but feeding level had a large influence on feed intake pattern. Animals fed the LLI consumed their feed within one hour, while those at HLI consumed their feed in several smaller meals (Figure 1).

\section{Degradability}

The fractions $S, D, U$ and $F$ together with $k_{\mathrm{d}}$ of the $\mathrm{OM}$ of the dietary ingredients and the calculated values for the total diets are shown in Table 4 . The $S$ fraction was much lower for dried beet pulp than for pressed beet pulp or maize silage. As a result the calculated $S$ fraction of diet DP was also lower. The $U$ fractions of the maize silages used were significantly higher than that of dried beet pulp or pressed beet 
Table 4. The soluble $(S)$, potentially fermentable $(D)$, undegradable fraction $(U)$ and total potentially rumen fermentable fraction $(F)(\%)$, rate of degradation $\left(k_{\mathrm{d}}\right)\left(\% \mathrm{~h}^{-1}\right)$ and lag time $(L)(\mathrm{h})$ in the organic matter of various feeds and rations as measured or estimated in sacco.

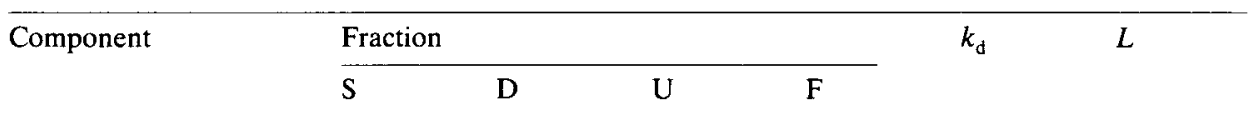

Ingredient

\begin{tabular}{lcccccc} 
Dried beet pulp & $6.3^{\mathrm{a}}$ & $88.0^{\mathrm{a}}$ & $5.7^{\mathrm{a}}$ & $94.3^{\mathrm{a}}$ & $5.59^{\mathrm{a}}$ & 3.36 \\
Pressed beet pulp & $34.5^{\mathrm{b}}$ & $62.4^{\mathrm{b}}$ & $3.1^{\mathrm{a}}$ & $96.9^{\mathrm{a}}$ & $6.16^{\mathrm{a}}$ & 0.53 \\
Maize silage No 11 & $38.8^{\mathrm{b}}$ & $33.1^{\mathrm{c}}$ & $28.1^{\mathrm{b}}$ & $71.9^{\mathrm{b}}$ & $3.45^{\mathrm{b}}$ & 3.82 \\
\multicolumn{1}{c}{ No 12 } & $32.4^{\mathrm{b}}$ & $41.5^{\mathrm{c}}$ & $26.1^{\mathrm{b}}$ & $73.9^{\mathrm{b}}$ & $2.62^{\mathrm{b}}$ & 0.00 \\
$\quad$ No D & $27.8^{\mathrm{b}}$ & $47.2^{\mathrm{c}}$ & $25.0^{\mathrm{b}}$ & $75.0^{\mathrm{b}}$ & $2.15^{\mathrm{b}}$ & 0.27 \\
Artificially dried grass & $27.5^{\mathrm{b}}$ & $55.9^{\mathrm{b}}$ & $16.6^{\mathrm{c}}$ & $83.4^{\mathrm{b}}$ & $3.09^{\mathrm{b}}$ & 1.19 \\
Concentrate & $51.0^{\mathrm{c}}$ & $42.2^{\mathrm{c}}$ & $5.7^{\mathrm{a}}$ & $93.2^{\mathrm{a}}$ & 4.48 & 0.39 \\
SED $^{2}$ & 2.09 & 2.62 & 3.72 & 3.76 & 0.25 &
\end{tabular}

Diets (average)

$\begin{array}{lllllll}\text { Dried beet pulp (DP) } & 31.5^{\mathrm{a}} & 56.1^{\mathrm{a}} & 12.4^{\mathrm{a}} & 86.6^{\mathrm{a}} & 4.40^{\mathrm{a}} & 1.49 \\ \text { Pressed beet pulp (PP) } & 38.6^{\mathrm{b}} & 49.7^{\mathrm{b}} & 11.7^{\mathrm{a}} & 88.3^{\mathrm{a}} & 4.40^{\mathrm{a}} & 0.78 \\ \text { Maize silage (M) } & 38.6^{\mathrm{b}} & 44.3^{\mathrm{b}} & 17.2^{\mathrm{b}} & 82.9^{\mathrm{b}} & 3.40^{\mathrm{b}} & 0.97 \\ \text { SED } & 1.40 & 1.45 & 1.81 & 1.94 & 0.23 & \end{array}$

${ }^{1}$ Maize silage No 11 = maize silage used in fermentation and feeding trial which was stored in silo No 11.

2 SED $=$ standard error of difference.

${ }^{3}$ Figures with a different superscript are significantly $(P<0.05)$ different.

pulp, resulting in a higher $U$ fraction for $\operatorname{diet} \mathrm{M}$, which resulted in a lower $F$ fraction for diet $\mathrm{M}$. The rate of $\mathrm{OM}$ degradation was lowest for maize silage and slightly higher yet similar for both beet pulps. The calculated $k_{\mathrm{d}}$ was lowest for diet M, while diets DP and PP were similar.

\section{Discussion}

The three diets compared favourably in their ash, N, crude fibre and NDF contents. The differences observed in sugar and starch contents are not considered to be influential (Table 1), because of the relatively low levels of these components in total rations. The rumen fermentation characteristics of the three TMR rations did not differ significantly in pH, total VFA, NGR and the major VFA's. This is in agreement with the chemical composition of the diets presented to the animals (Table 1, Table 3). The results of this experiment agreed with previous findings. Only small, if any differences were observed in rumen fermentation characteristics for dried beet pulp and pressed beet pulp diets (Battacharya \& Lubbadah, 1971; Castle, 1972; Huhtanen, 1988) or between diets based on beet pulp or maize silage (Verite, 1975).

Results from the nylon bag incubation study showed differences in the $S$ fraction between diet DP on the one hand and the diets PP and M on the other. The chemi- 
cal composition of the $S$ fraction was not analysed, but the fraction in dried beet pulp was very small and probably consisted mainly of sugars. The ground dry material probably swelled during the washing programme, increasing particle size and therefore reducing the number of very small particles, which could be rinsed out of the nylon bags. Pressed beet pulp and maize silage had higher $S$ fractions, yet again the chemical composition of these fractions was not analysed. However, the remaining sugars, part of the starch and the fermentation end-products of pressed ensiled beet pulp and maize silage may have been removed from the nylon bags during washing. Furthermore, these components do not account for all the material which was measured as the soluble fraction. Fermentation processes in the silo may convert other components into more soluble fractions and/or reduce their particle size, increasing their possibility of being washed out of the bags. Courtin \& Spoelstra (1989) suggested that pectins, present to a large extent in beet pulp, could be degraded by enzymes produced by yeasts and species of the bacterial genus Bacillus into smaller particles during the ensiling process, which could explain differences in the $S$ fraction between dried beet pulp and pressed beet pulp.

A larger quantity of soluble $\mathrm{OM}$, which is assumed to be available for fermentation immediately after feed intake, was expected to affect rumen fermentation characteristics. The $S$ fraction was higher for diets PP and M than for diet DP. Nevertheless, this was not reflected in the concentration of the major VFA's, the pH of the rumen fluid, or the daily variation of these parameters.

When using the results of the degradation study to explain rumen fermentation characteristics, it seems therefore acceptable to use the total rumen degradable fraction $(F)$, because this fraction was similar for both beet pulp diets. The results of the nylon bag incubation study showed a significant difference in the $U$ fraction between maize silage and both beet pulps. This is in agreement with differences in organic matter digestibility measured in vivo and in vitro, for maize silage (72\%) and beet pulp ( $89 \%$ ) (de Visser \& Hindle, 1990).

The higher $U$ fraction for diet M, in comparison to both beet pulp diets (Table 4) did not result in differences in $\mathrm{pH}$ or concentration of the major VFA's (Table 3).

A lower rate of degradation $\left(k_{\mathrm{d}}\right)$ was calculated for diet $\mathrm{M}$, when compared to both beet pulp diets (Table 4), but it did not affect rumen fermentation, with regard to $\mathrm{pH}$ and the concentration of the major VFA's (Table 3 ).

In this experiment only the OM degradation was measured.

Probably the difference in fermentation pattern between NDF and starch, the increase of VFA, due to a reduced liquid/OM ratio (Sutherland, 1988) and the negative influence of a lower degradability were compensating each other, resulting in similar concentrations of VFA between both beet pulp and the maize silage diets.

The higher $U$ fraction of the $\mathrm{OM}$ and the lower rate of OM degradation were thought to be responsible for the reduced total dry matter intake of diet $\mathrm{M}$, compared to both beet pulp rations, as measured in the feeding trial of de Visser \& Hindle (1990), because those animals were fed ad libitum. In this experiment the animals were restricted in intake and no differences in DM intake were found.

The lower $F$ fraction and the reduced $k_{\mathrm{d}}$ of diet $\mathrm{M}$ resulted in a lower availability of energy components for the synthesis of microbial protein (van Straalen \& Tam- 
minga, 1990), leading to increased concentrations of BCFA, valerate and ammonia (Table 3), which agreed with the results of Miller (1982), van Soest (1982) and Robinson et al. (1986).

The results of the feeding trial of de Visser \& Hindle (1990), in which a reduced milk protein content was found on the maize silage diet, might have been the result of the lower microbial protein synthesis, especially in early lactation, when the animals are fed below both energy and protein requirements.

The level of feed intake significantly influenced rumen fermentation, which can be explained by the larger quantity of rumen fermentable OM, which was available at HLI, compared to LLI (Table 3). This agrees with the results of Hodgson et al. (1976), who also found increased concentrations of VFA at higher levels of intake. Robinson et al. (1986) showed a linear relationship between the OM intake and rumen pool size. The ratio liquid/solids was reduced at higher intakes, increasing concentrations of VFA. At LLI the daily variation of the concentrations were significantly higher for ammonia, total VFA, NGR, acetate and propionate. This is thought to be a result of the difference in feed intake patterns (Fig. 1), providing a more constant supply of rumen degradable OM at the high level of intake.

The results of the fermentation and degradation studies confirmed the results of the feeding trial, but more information concerning the degradation of the various OM fractions is required to enable a more precise explanation of fermentation patterns.

\section{Acknowledgements}

The authors wish to thank Mr L. de Jong and Mr J. Truin for taking care of the animals.

Further the authors are particularly grateful for the financial support received from the Sugar Research Institute (IRS, Bergen op Zoom). Our special thanks goes to the CSM sugar mill 'Wittouck' in Breda for delivery of the sugar beet pulp.

\section{References}

Alvey, N., N. Galway \& P. Lane, 1982. An introduction to Genstat. p. 255, Academic Press, London.

Bhattachrya, A. N. \& W. F. Lubbadah, 1971. Feeding high levels of beet pulp in high concentrate dairy rations. Journal of Dairy Science 54: 95-99.

Castle, M. E., 1972. A comparative study of the feeding value of dried sugar-beet pulp for milk production. Journal of Agricultural Science (Cambridge) 78: 371-377.

Courtin, M. G. \& S. F. Spoelstra, 1989. Counteracting structure loss in pressed sugar beet pulp silage. Animal Feed Science and Technology 24: 97-109.

Hemingway, R. G., J. J. Parkins \& J. Frazer, 1986. Sugar beet pulp products for dairy cows. Animal Feed Science and Technology 15: 123-127.

Hodgson, J. C., P. C. Thomas \& A. G. Wilson, 1976. The influence of the level of feeding on fermentation in the rumen of sheep receiving a diet of ground barley, ground hay and flaked maize. Journal of Agricultural Science (Cambridge) 87: 297-302.

Huhtanen, 1988. The effects of barley, unmolassed sugar-beet pulp and molasses supplements on organic matter, nitrogen and fibre digestion in the rumen of cattle given a silage diet. Animal Feed Science and Technology 20: 259-278. 
Miller, E. L., 1982. The nitrogen needs of ruminants. Occasional Publication of the British Society of Animal Production 6: 79-88.

$\emptyset$ rskov, E. R., 1975. Manipulation of rumen fermentation for maximum food utilisation. World Review of Nutrition and Dietetics 22: 152-182.

Robinson, P. H., S. Tamminga \& A. M. van Vuuren, 1986. Influence of declining level of feed intake and varying the proportion of starch in the concentrate on rumen fermentation in dairy cows. Livestock Production Science 15: 173-189.

Robinson, P. H., S. Tamminga \& A. M. van Vuuren, 1987. Influence of wet vs. dry by-product ingredients and addition of branched-chain volatile fatty acids and valerate to dairy diets. 2 . Rumen fermentation and milk production. Netherlands Journal of Agricultural Science 35: 459-471.

Soest, P. van, 1982. Nutritional ecology of the ruminant. O \& B books, Corvallis, OR, USA. 374 pp.

Straalen, W. M. van \& S. Tamminga, 1990. Protein degradation of ruminant diets. In: J. Wiseman \& J. A. C. Cole (Eds), Feed evaluation, p. 55-72. Butterworths, London.

Sutherland, T. M., 1988. Particle separation in the forestomachs of sheep. In: A. Dobson \& M. J. Dobson (Eds), Aspects of digestive physiology in ruminants, p. 43-73. Comstock Publishing Associates, London.

Verite, R., 1975. Utilisation comparée pour la production de lait de 3 rations à base de betteraves, de pulpes de betteraves ou d'ensilage de mais: utilisation de l'énergie et aspects digestifs et métaboliques. Annales Zootechnique 24: 373-390.

Visser, H. de \& V. A. Hindle, 1990. Dried beet pulp, pressed beet pulp and maize silage, as substitutes for concentrates in dairy cow rations. 1. Feeding value, feed intake, milk production and milk composition. Netherlands Journal of Agricultural Science 38: 77-88.

Visser, H. de \& S. Tamminga, 1987. Influence of wet vs. dry by-product ingredients and addition of branched-chain volatile fatty acids and valerate to dairy diets. 1. Feed intake, milk production and milk composition. Netherlands Journal of Agricultural Science 35: 163-175.

Vuuren, A. M. van, K. Bergsma, F., Krol-Kramer \& J. A. C. van Beers, 1989. Effects of addition of cell wall degrading enzymes on the chemical composition and in sacco degradation of grass silage. Grass and Forage Science 44: 223-230. 